\title{
Akridon és akridin egységet tartalmazó koronaéter alapú szenzor- és szelektormolekulák szintézise, kation- és enantiomerfelismerése
}

\author{
NÉMETH Tamás, ${ }^{a}$ BALOGH György Tibor, ${ }^{b}$ VÉRTESSY G. Beáta, ${ }^{\mathrm{c}, \mathrm{d}}$ HUSZTHY Péter, ${ }^{\mathrm{a}}$ és \\ TÓTH Tünde, ${ }^{\mathrm{a}, *}$ \\ ${ }^{a}$ Budapesti Müszaki és Gazdaságtudományi Egyetem, Szerves Kémia és Technológia Tanszék, \\ Szent Gellért tér 4., 1111, Budapest, Magyarország \\ ${ }^{b}$ Richter Gedeon Nyrt., Szintézistámogató Laboratórium, Gyömrői út 19-21., 1103, Budapest, Magyarország \\ ${ }^{c}$ Magyar Tudományos Akadémia TTK, Enzimológiai Intézet, Magyar tudósok krt. 2., 1117, Budapest, Magyarország \\ 'Budapesti Müszaki és Gazdaságtudományi Egyetem, Alkalmazott Biotechnológia és Élelmiszertudományi Tanszék,
} Szent Gellért tér 4., 1111, Budapest, Magyarország

\section{Bevezetés}

Napjainkban széleskörü tudományos érdeklődés irányul a különböző fémionok, illetve királis vegyületek enantiomerjeinek egyre szelektívebb felismerését biztosító szenzormolekulák, valamint az ezek elválasztását is lehetővé tevő szelektormolekulák kifejlesztésére, mivel alkalmazásukra a gyógyszeriparban, az élelmiszeriparban és a környezetvédelemben is lehetőség nyílik. Ezen vegyületek szelektív komplexképző tulajdonságainak alapja a molekuláris felismerés jelensége, amely a legjobban két vagy több molekula közötti szelektív megkülönböztetésként jellemezhető, amely során másodlagos (nem kovalens) kölcsönhatások kialakulása révén rendezett szerkezetek, komplexek keletkeznek. A molekuláris felismerés fogalmát Emil Fischer dolgozta ki 1894-ben, mikor egy adott enzim adott szubsztráthoz való specifikus kötődését a „kulcs-zár” elmélettel magyarázta. A szupramolekuláris kémia fogalmának bevezetése pedig Jean-Marie Lehn nevéhez füzödik: véleménye szerint ez úgy határozható meg, mint "kémia a molekulán túl"1. Az egyre szélesebb körben terjedő szupramolekuláris kémia másodlagos kötőerőkkel összetartott molekuláris asszociátumok keletkezésével, tulajdonságainak és alkalmazási lehetőségeinek vizsgálatával foglalkozik. Mióta az egyik úttöröje az ilyen irányú kutatásoknak, Charles J. Pedersen, publikálta az első szintetikus gazdamolekulák, a koronaéterek szintézisét és vizsgálatát ${ }^{2,3}$, ez a kutatási terület jelentős érdeklődésre tett szert ${ }^{4}$. E terület elismerését jelzi, hogy a nagy szelektivitással rendelkező szerkezet-specifikus kölcsönhatások kialakítására képes molekulák kifejlesztésért Charles J. Pedersennek, Donald J. Cramnek és Jean-Marie Lehnnek ítélték oda az 1987. évi kémiai Nobel-díjat. A 2016. évi kémiai Nobel-díjat Jean-Pierre Sauvage, Sir J. Fraser Stoddart és Bernard L. Feringa kapta molekuláris gépek fejlesztéséért, amely azt mutatja, hogy a kémia e területe most is nagy érdeklődésre tart számot.

Az első enantiomertiszta koronaéter szintézisét Stoddart és Szarek valósította $\mathrm{meg}^{5}, D$-(-)-ribózból kiindulva szénhidrát alapú makrociklust szintetizált (1, 1. ábra). Cram munkatársaival egy axiális kiralitással rendelkező bisz(1,1'-binaftil)-22-korona-6-étert $[(S, S)$-2, 1. ábra] állított elő és elsőként vizsgálta enantiomer-megkülönböztető képességét ${ }^{6}$.<smiles>OC1=C(O)C2OCC3OC4OCC(OC3OCC1O2)C(O)[C@@H]4O</smiles><smiles>C1=CC2=C(c3ccccc3C=C1)c1ccccc1C=CC1=C(c3ccc4ccccc4c3-c3c(ccc4ccccc34)OCCOCCO1)c1c(ccc3ccccc13)OCCOCCO2</smiles>

$(S, S)-2$

\section{1. Ábra. Az első királis koronaéterek}

Később bebizonyosodott, hogy a molekuláris- és enantiomerfelismerés során a hidrogénkötés mellett egyéb másodlagos kölcsönhatások, mint például a $\pi-\pi$ kölcsönhatás ${ }^{7}$ és kation- $\pi^{8}$ kölcsönhatás, is nagy jelentőséggel bír. Új alkalmazási lehetőségek keresése során a koronaéterek szerkezetének kiterjedt módosítására került sor. A szakirodalomból számos példa ismert a makrogyürüben heterociklusos egységet tartalmazó koronaéterekre. Ezek a vegyületek gyakran több, másodlagos kölcsönhatások kialakítására képes kötőhellyel rendelkeznek, amelyek a makrociklusok szerkezetének merevségét növelhetik, elönyösen befolyásolva szelektivitásukat és komplexképző tulajdonságaikat. Számos ilyen makrociklus $N$-heterociklusos (például piridin ${ }^{9}$, pirimidin, triazin vagy triazol) egységet tartalmaz. Királis szerves ammóniumsókkal szemben mutatott enantiomer-megkülönböztető képességüket titrálásos kalorimetriával, kromatográfiával, cirkuláris dikroizmus spektroszkópiával, NMR-spektroszkópiával és elektrokémiai módszerekkel tanulmányozták ${ }^{10}$. Egykristály röntgendiffrakciós mérések igazolták ${ }^{11}$, hogy a Prikle és Pochapsky által leírt „hárompontos szabállyal”

\footnotetext{
* Tünde Tóth. Tel.: 06-1-463-2111; fax: 06-1-463-3297; e-mail: ttoth@mal.bme.hu

A közlemény alapjául Németh Tamás "Synthesis and molecular recognition studies of acridono- and acridino-crown ether-based sensor and selector molecules" címú doktori értekezése szolgált, mely a https://doktori.hu/index.php?menuid=193\&lang=HU\&vid=17939 oldalon érhető el.
} 
összhangban ${ }^{12}, N$-heterociklusos egységet (mint például piridin és akridin) tartalmazó makrociklusok enantiomer-megkülönböztető képessége három eltérő kölcsönhatáson alapul, melyek közül legalább egynek sztereokémia-függőnek kell lennie: i.) hárompontos hidrogénkötés kialakulása a gazdamolekula nitrogénatomja és két alternáló oxigénatomja, valamint az ammóniumsó vendégmolekula három protonja között, ii.) $\pi-\pi$ kölcsönhatás a gazdamolekula heteroaromás gyürürendszere és a vendégmolekula aromás csoportja között, iii.) továbbá sztérikus gátlás a gazdamolekula kiralitáscentrumain található szubsztituensek és a vendégmolekula egyes csoportjai közt.

A heterociklusos egység gyürürendszerének kiterjesztésével a kation $-\pi$ és $\pi-\pi$ kölcsönhatások növelhetők, így fordult a figyelem a kiterjedt aromás rendszerek, mint például az akridin és akridon egység felé. A triciklusos heteroaromás gyürürendszer merevebbé teszi a koronaéter konformációját, mely tovább növelheti a szelektivitást. Továbbá fluoro- és kromogén sajátságuk révén komplexképzésük az igen érzékeny fotofizikai módszerekkel (UV-vis és fluoreszcencia spektroszkópiával) is vizsgálható. Ezen okok miatt az elmúlt évtizedben számos akridin és akridon egységet tartalmazó szenzormolekula előállítását és vizsgálatát tüzték ki célul hazai kutatócsoportok ${ }^{13-17}$. Szenzorként való alkalmazásuk mellett a koronaéterek szelektorként alkalmazva megfelelőek lehetnek királis szerves vegyületek enantiomerjeinek elválasztására. A számos különböző elválasztási módszer közül a királis állófázis (CSP) segítségével működő folyadékkromatográfia bizonyítottan az egyik legpontosabb és leghatékonyabb módszer a fent említett feladatok elvégézésre ${ }^{18}$. Számos $N$-heterociklusos egységet tartalmazó állófázist állítottak elő szelektor molekulák kovalens kötésekkel szilárd hordozóhoz történő rögzítésével. Csoportosításuk az alkalmazott szilárd hordozó alapján történhet. Megkülönböztetünk hagyományos szilikagél ${ }^{19-22}$, Merrifield-féle polimer gyanta ${ }^{23}$, HPLC minőségü szilikagél ${ }^{24}$, valamint HPLC minőségű szférikus szilikagél hordozós állófázist ${ }^{25}$. Munkám kezdetéig a szakirodalomból csak egyetlen akridin egységet tartalmazó állófázis volt ismert ${ }^{26}$. Lakatos és munkatársai egy terminális kettőskötésü oldallánccal rendelkező makrociklust [(R,R)-3] $\gamma$-merkaptopropil- csoporttal módosított HPLC minőségü szilikagélhez rögzítve jutottak új királis állófázishoz $[(R, R)-\mathrm{CSP}-4,2$. ábra].

Figyelembe véve az összes korábban említett előnyt, az akridin egységet tartalmazó állófázisok esetében nagyobb mértékü enantiomerfelismerés volt várható, mint a kutatócsoportunkban korábban már részletesen vizsgált piridin egységet tartalmazóké, ezért előállításuk nagy érdeklődésre tartott számot.

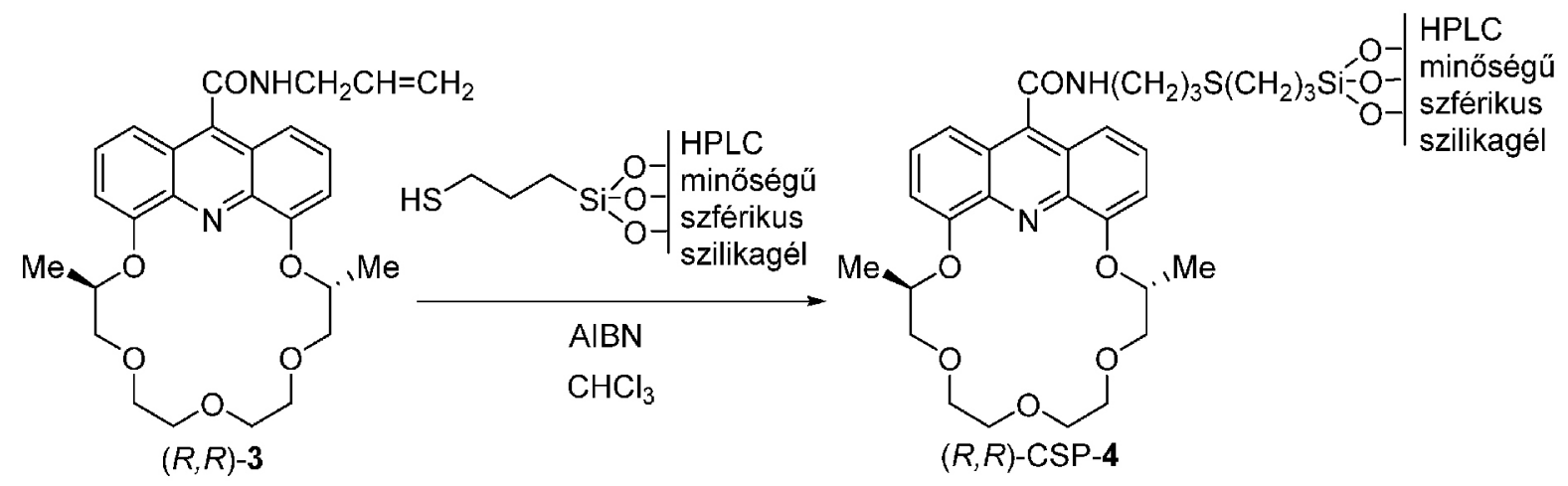

2. Ábra. Az első akridino-koronaéter alapú királis állófázis előállítása

\section{Eredmények}

\section{1. Új, királis állófázisok szintézise}

A koronaéterek szintézisének kulcslépése a makrociklizáció. Ezeket a bimolekuláris nukleofil szubsztitúciós $\left(\mathrm{S}_{\mathrm{N}} 2\right)$ reakciókat bázis $\left(\mathrm{K}_{2} \mathrm{CO}_{3}\right)$ jelenlétében, acetonitrilben hajtottuk végre. $\mathrm{Az} \mathbf{5}^{26}$ formamid és a diizobutil-, illetve dimetilszubsztituált tetra- vagy pentaetilénglikol-di- $p$-toluolszulfonát származékok $[(S, S)-\mathbf{6 a},(S, S)-\mathbf{6 b},(S, S)-\mathbf{6 c}$ és $(S, S)$-6d $]$ gyürüzárásával az $(R, R)-\mathbf{7 a},(S, S)-\mathbf{7 b},(S, S)-7 \mathbf{c}$ és $(R, R)-\mathbf{7 d}$ makrociklusokhoz jutottunk ${ }^{27,28}$ (3. ábra). Az $(S, S)-6 a^{29}$ és $(S, S)-6 \mathbf{b}^{15}$ tetraetilénglikol-ditozilátokat, illetve az $(S, S)-6 \mathbf{c}^{30}$ pentaetilénglikol-ditozilátot irodalmi eljárás alapján állítottuk elő. Az $(S, S)-6 \mathbf{d}$ ditozilátot pedig a megfelelő diol $^{31}$ és tozil-klorid reakciójával nyertük ${ }^{28}$. Az $(R, R)-7 \mathbf{a}$ makrociklus nitrogénjéről a formil védőcsoportot vizes etanolos kálium-hidroxiddal távolítottuk el. Az $(S, S)-7 \mathbf{b}$,
$(S, S)$-7c és $(R, R)$-7d vegyületek esetében, a célvegyületek $[(S, S)-8 \mathbf{b},(S, S)-8 \mathbf{c}$ és $(R, R)-8 d]$ erős káliumion komplexáló hajlama miatt az alkálifém-hidroxidok helyett vizes metanolos sósav alkalmazásával távolítottuk el a formil védőcsoportot, így jó termeléssel jutottunk a kívánt szekunder aminokhoz (3. ábra $)^{27,28}$. Az utóbbi makrociklusok szekunder aminocsoportját oxalil-kloriddal acileztük toluolban, majd az ezt követő katalítikus mennyiségü jód jelenlétében brómbenzolban végzett Friedel-Crafts-reakcióval a kívánt új izatin-származékokat kaptuk $[(R, R)-\mathbf{1 0 a},(S, S)-\mathbf{1 0 b},(S, S)-\mathbf{1 0 c}$ és $(R, R)-\mathbf{1 0 d}] . \mathrm{Az}$ új, karboxilcsoportot tartalmazó, akridino-18-korona-6- és akridino-21-korona-7-étereket $\quad[(R, R)-\mathbf{1 1 a}, \quad(S, S)-\mathbf{1 1} \mathbf{b}$, $(S, S)-11 \mathrm{c}, \quad(R, R)-11 \mathrm{~d}$ és $(R, R)-\mathbf{1 1 d}]$ a megfelelö új izatinokból $[(R, R)-\mathbf{1 0 a},(S, S)-\mathbf{1 0 b},(S, S)-\mathbf{1 0 c},(R, R)-\mathbf{1 0 d}]$, és az irodalomból már ismert $(R, R)-\mathbf{1 0 e}^{26}$ analogont is, vizes tetrametil-ammónium-hidroxidot alkalmazva állítottuk elö (3. ábra). 


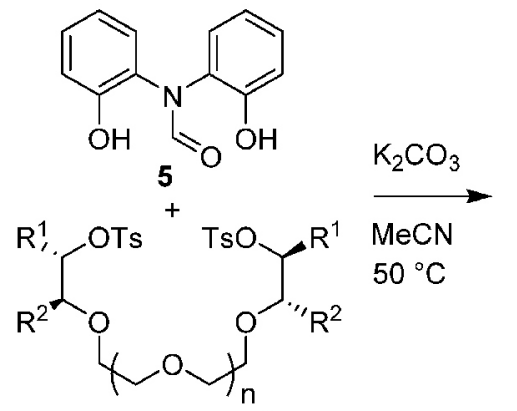

$(S, S)-6 a: R^{1}=i B u, R^{2}=H, n=1$

$(S, S)-6 b: R^{1}=H, R^{2}=M e, n=1$

(S,S)-6c: $R^{1}=H, R^{2}=M e, n=2$

$(S, S)-6 d: R^{1}=M e, R^{2}=H, n=2$

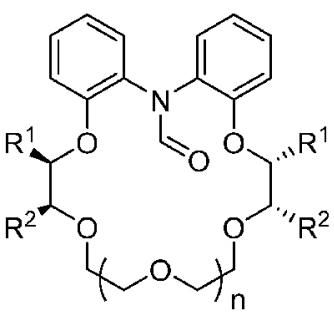

$\underset{\text { vagy } \mathrm{HCl} / \mathrm{MeOH} / 50^{\circ} \mathrm{C}}{\stackrel{\mathrm{KOH} / \mathrm{EtOH} / 50^{\circ} \mathrm{C}}{\longrightarrow}}$

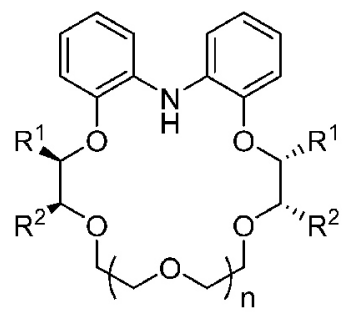

$(R, R)-7 \mathrm{a}: \mathrm{R}^{1}=\mathrm{iBu}, \mathrm{R}^{2}=\mathrm{H}, \mathrm{n}=1(37 \%)$

$(S, S)-7 b: R^{1}=H, R^{2}=M e, n=1(72 \%)$

$(S, S)-7 c: R^{1}=H, R^{2}=M e, n=2(66 \%)$

$(R, R)-7 \mathrm{~d}: \mathrm{R}^{1}=\mathrm{Me}, \mathrm{R}^{2}=\mathrm{H}, \mathrm{n}=2(67 \%)$
$(R, R)-8 \mathrm{a}: \mathrm{R}^{1}=\mathrm{iBu}, \mathrm{R}^{2}=\mathrm{H}, \mathrm{n}=1(92 \%)$

$(S, S)-8 \mathbf{b}: R^{1}=H, R^{2}=M e, n=1(82 \%)$

$(S, S)-8 c: R^{1}=H, R^{2}=M e, n=2(89 \%)$

$(R, R)-8 \mathrm{~d}: \mathrm{R}^{1}=\mathrm{Me}, \mathrm{R}^{2}=\mathrm{H}, \mathbf{n}=2(89 \%)$

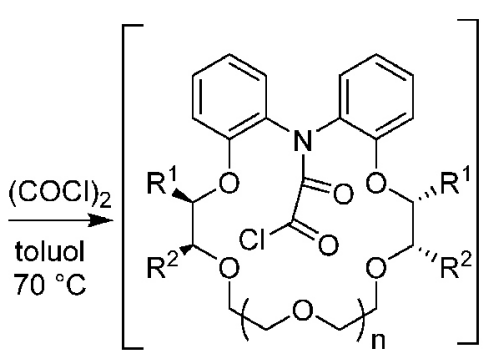

$(R, R)-9 \mathrm{a}: \mathrm{R}^{1}=\mathrm{iBu}, \mathrm{R}^{2}=\mathrm{H}, \mathrm{n}=1$ $(S, S)-9 b: R^{1}=H, R^{2}=M e, n=1$ $(S, S)-9 c: R^{1}=H, R^{2}=M e, n=2$ $(R, R)-9 \mathrm{~d}: \mathrm{R}^{1}=\mathrm{Me}, \mathrm{R}^{2}=\mathrm{H}, \mathrm{n}=2$

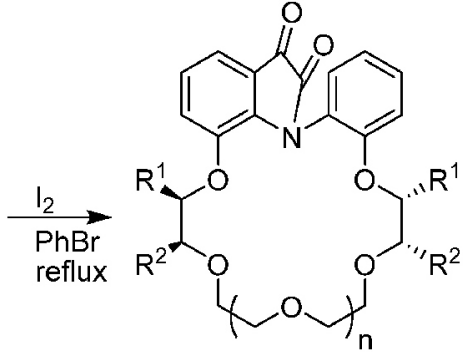

$(R, R)-10 \mathrm{a}: \mathrm{R}^{1}=\mathrm{iBu}, \mathrm{R}^{2}=\mathrm{H}, \mathrm{n}=1(21 \%)$ $\left.(S, S)-10 b: R^{1}=H, R^{2}=M e, n=112 \%\right)$ $(S, S)-10 \mathrm{c}: \mathrm{R}^{1}=\mathrm{H}, \mathrm{R}^{2}=\mathrm{Me}, \mathrm{n}=2(14 \%)$ $(R, R)-10 \mathrm{~d}: \mathrm{R}^{1}=\mathrm{Me}, \mathrm{R}^{2}=\mathrm{H}, \mathrm{n}=2(15 \%)$ $(R, R)-10 \mathrm{e}: \mathrm{R}^{1}=\mathrm{Me}, \mathrm{R}^{2}=\mathrm{H}, \mathrm{n}=1$<smiles>[R]C(OC)C([R])Oc1cccc2c(C(=O)O)c3cccc(OC([R])C([R])OCCOCCOCCO[Na])c3nc12</smiles>

$(R, R)-11 \mathrm{a}: \mathrm{R}^{1}=\mathrm{iBu}, \mathrm{R}^{2}=\mathrm{H}, \mathrm{n}=1(33 \%)$ $(S, S)-11 b: R^{1}=H, R^{2}=M e, n=1(20 \%)$ $(S, S)-11 c: R^{1}=H, R^{2}=M e, n=2(41 \%)$ $(R, R)-11 \mathrm{~d}: \mathrm{R}^{1}=\mathrm{Me}, \mathrm{R}^{2}=\mathrm{H}, \mathrm{n}=2(58 \%)$ $(R, R)-11 \mathrm{e}: \mathrm{R}^{1}=\mathrm{Me}, \mathrm{R}^{2}=\mathrm{H}, \mathrm{n}=1(50 \%)$

3. Ábra. 9-Akridinkarbonsav egységet tartalmazó enantiomertiszta koronaéterek szintézise

$\mathrm{Az} \quad(R, R)-\mathbf{1 1 a} \quad$ és $\quad(R, R)-\mathbf{1 1} \mathbf{e}$ karbonsavak 3-aminopropiltrietoxiszilánnal (APTS) való reakciója az $(R, R)$-12a és $(R, R)-\mathbf{1 2 b}$ amid funkciós csoportot tartalmazó trietoxiszilil-végcsoportú származékokat eredményezte ${ }^{27}$. A APTS acliezését $\quad N, N^{\prime}$-diciklohexilkarbodiimid alkalmazásával diklórmetánban valósítottuk meg. A trietoxiszilil-végcsoportot tartalmazó koronaéter származékokat szférikus HPLC minőségű szilikagéllel forró toluolban kevertetve az $(R, R)$-CSP-13a és $(R, R)$-CSP-13b királis állófázisokat nyertük (4. ábra $\mathrm{A})$. Ezt a módszert hagyományos szakaszos eljárásnak nevezik.

Általánosan elfogadott, hogy HPLC oszlopok töltésére a kis viszkozitású zagytöltés a legalkalmasabb módszer ${ }^{32}$. Annak érdekében, hogy ezt a vélekedést vitassuk, kidolgoztunk egy új eljárást királis állófázisok előállítására ${ }^{33}$. A folyamatos áramlásos kémia alkalmazásával, többlépéses reakcióban, egy akridino-18-korona-6-éter alapú királis állófázist állítottunk elö. $\mathrm{Az}(R, R)$-CSP-13c állófázist az $(R, R)-\mathbf{1 1 e}$ királis akridino-koronaéterből kiindulva szintetizáltuk (4. ábra $\mathrm{B})$. Az $(R, R)$-11e karbonsav, APTS és DCC oldatát, magas hőmérsékleten és nagy nyomáson, folyamatos áramban egy szelektort nem tartalmazó szilikagéllel töltött HPLC oszlopon (SP-14) keresztül addig áramoltattuk, míg kiépült a kovalens kötés a HPLC minőségü szilikagél és a királis szelektormolekula között (4. ábra) ${ }^{33}$.

Tanulmányozni szerettük volna a kiralitáscentrumok helyzetének az enantiomer-megkülönböztető képességre gyakorolt hatását, ezért az $(S, S)$-11b karbonsavból kiindulva előállítottuk az $(S, S)$-CSP-13d állófázist (4. ábra $C)^{28}$. A karbonsavat először katalitikus mennyiségü DMF jelenlétében $\mathrm{SOCl}_{2}$-dal reagáltattuk, majd a kapott savkloridot, bomlékonysága miatt, azonnal APTS-al reagáltattuk diklórmetánban. $\mathrm{Az} \quad(S, S)-\mathbf{1 5}$ koronaétert tisztítás nélkül, szférikus HPLC minőségü szilikagéllel toluolban forralva az $(S, S)$-CSP-13d állófázist kaptuk ${ }^{28}$. Ez a módszer gyorsabb volt és jobb termelést adott, mint az $(S, S)$-CSP-13b állófázis szintézisénél bemutatott eljárás.

A megfelelő szelektort tartalmazó módosított szférikus HPLC minőségü szilikagélt $\quad[(R, R)$-CSP-13a, $(R, R)$-CSP-13b és $(S, S)$-CSP-13d] 500 bar nyomáson, kis viszkozitású zagytöltés módszerével $150 \times 4 \mathrm{~mm}$ méretü HPLC oszlopokba töltöttük ${ }^{27,28}$. 

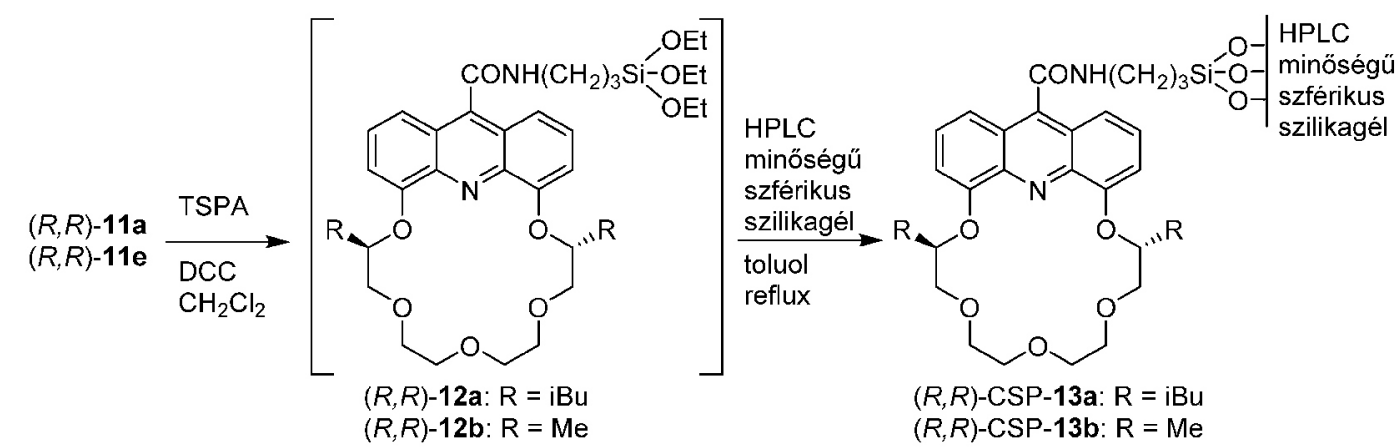

$(R, R)-C S P-13 \mathrm{~b}: \mathrm{R}=\mathrm{Me}$

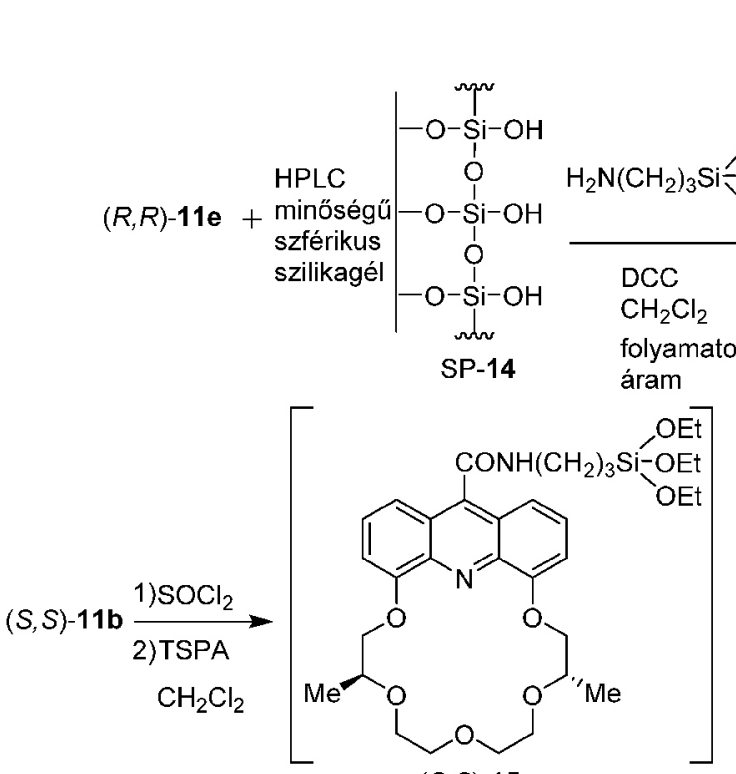

$(S, S)-15$<smiles>CCCCOCCOCC(C)Oc1cccc2c(C(N)=O)c3cccc(OC(C)CC)c3nc12</smiles>

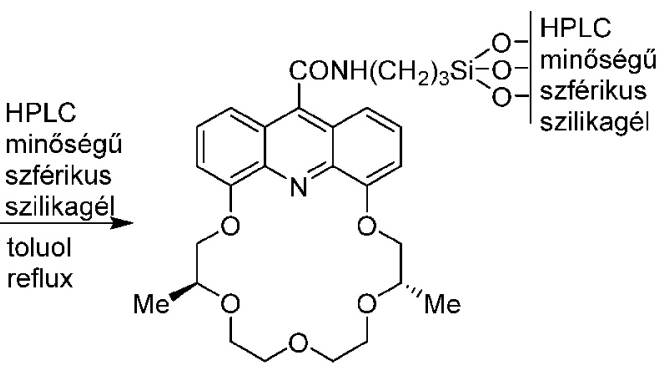

$(S, S)$-CSP-13d

4. Ábra. Az állófázisok előállitása

\subsection{A királis állófázisok enantiomer-elválasztó képességének tanulmányozása}

Az akridino-18-korona-6-éter szelektormolekulát tartalmazó királis állófázisok aromás csoportot tartalmazó protonált primer amin-származékok [1-(1-naftil)etilamin (1-NEA), 1-(2-naftil) etilamin (2-NEA), 1-(4-brómfenil)etilamin (Br-PEA), 1-(4-nitrofenil)etilamin $\quad\left(\mathrm{NO}_{2}\right.$-PEA) $\quad$ enantiomerjeivel szemben mutatott elválasztó képességét HPLC alkalmazásával vizsgáltuk (1. Táblázat) $27,28,33$. Minden esetben $1,0 \mathrm{ml} /$ perc áramlási sebességet és izokratikus elúciót alkalmaztunk.

Valamennyi vizsgált amin-származék esetében az $(R)$-enantiomernek volt kisebb a retenciós ideje, mint az antipódjának. $\quad \mathrm{Az} \quad(R, R)$-CSP-13a, $\quad(R, R)$-CSP-13b és $(R, R)$-CSP-13c állófázisok esetében ez az elúciós sorrend a heterokirális komplexek $[(R, R)$-koronaéter- $(S)$-ammónium só $]$ homokirális komplexekhez $[(R, R)$-koronaéter- $(R)$-ammónium só] viszonyított nagyobb stabilitását jelzi. Ez a megfigyelés teljes mértékben megegyezik az általunk, $N$-heterociklus egységet tartalmazó koronaéter alapú, szilikagélhez rögzített királis állófázisok vizsgálatánál tapasztaltakkal ${ }^{26}$. Ezzel ellentétben az $(S, S)$-CSP-13d állófázis esetében az elúciós sorrend a homokirális komplexek nagyobb stabilitását jelzi. Ez a megfigyelés a kiralitáscentrumok helyzetének változtatásával magyarázható. A kiralitáscentrumok az akridin egységtől egy szénatommal való távolabb helyezésével a sztérikus gátlás (egy jelentős tényező, amely befolyásolja az enantiomer-megkülönböztetés mértékét) erössége csökken. Egyéb másodlagos kölcsönhatások, mint például a hidrogénkötés és a $\pi$ - $\pi$ kölcsönhatás, átveszik a meghatározó szerepet az enantiomer-megkülönböztetést illetően.

Összevetve az $(R, R)$-CSP-13a és $\quad(R, R)$-CSP-13b állófázisokat megállapítható, hogy valamennyi vizsgált amin-származékra a királitáscentrumain izobutilcsoportot tartalmazó $(R, R)$-CSP-13a királis állófázis mutatott nagyobb enantiomerszelektivitást (1. Táblázat). Ez a metilcsoportokhoz képest nagyobb térkitöltésü izobutilcsoportok jelenlétével magyarázható. A vizsgált vegyületekre a legnagyobb szelektivitást ( $\alpha$ értékek) az izobutilcsoportot tartalmazó $(R, R)$-CSP-13a királis állófázis mutatta, a legnagyobb felbontást $\left(\mathrm{R}_{\mathrm{S}}\right.$ értékek) pedig a folyamatos áramoltatással elóállított állófázissal $[(R, R)-\mathrm{CSP}-13 \mathrm{c}]$ sikerült elérni. Az utóbbi állófázis nagyobb retenciós időket, nagyobb szelektivitást és hatékonyságot mutatott a protonált 1-NEA, 2-NEA és Br-PEA enantiomerekre, mint a dimetil-szubsztituált, hagyományos szakaszos eljárással előállított állófázis $[(R, R)$-CSP-13b]. 
1. Táblázat. A királis állófázisoknak a vizsgált protonált primer aralkil-aminok esetében elért enantiomer-elválasztási adatai

\begin{tabular}{|c|c|c|c|c|c|c|}
\hline Analit & CSP & $\begin{array}{c}t(R) \\
{[\text { perc] }}\end{array}$ & $\begin{array}{c}t(S) \\
{[\text { perc] }}\end{array}$ & $\alpha$ & $R_{\mathrm{s}}$ & Eluens \\
\hline \multirow[t]{4}{*}{ 1-NEA } & $(R, R)$-CSP-13a & - & - & - & - & $\bar{A}$ \\
\hline & $(R, R)$-CSP-13b & 1,96 & 3,49 & 1,78 & 2,46 & $\mathrm{~B}$ \\
\hline & $(R, R)-\mathrm{CSP}-\mathbf{1 3 c}$ & 6,91 & 12,87 & 1,86 & 2,53 & $\mathrm{C}$ \\
\hline & $(S, S)-C S P-13 d$ & 11,02 & 13,51 & 1,23 & 1,20 & $\mathrm{D}$ \\
\hline \multirow[t]{4}{*}{ 2-NEA } & $(R, R)-C S P-13 \mathbf{a}$ & 6,29 & 12,9 & 2,05 & 2,70 & A \\
\hline & $(R, R)$-CSP-13b & 1,85 & 3,12 & 1,68 & 1,79 & $\mathrm{~B}$ \\
\hline & $(R, R)$-CSP-13c & 8,09 & 14,31 & 1,77 & $\mathbf{3 , 3 1}$ & $\mathrm{C}$ \\
\hline & $(S, S)-C S P-13 d$ & 15,96 & 16,35 & 1,02 & $<0,2$ & E \\
\hline \multirow[t]{4}{*}{ Br-PEA } & $(R, R)-C S P-13 \mathbf{a}$ & 5,19 & 9,95 & 1,92 & 2,06 & A \\
\hline & $(R, R)$-CSP-13b & 1,75 & 2,74 & 1,57 & 1,55 & $\mathrm{~B}$ \\
\hline & $(R, R)$-CSP-13c & 6,98 & 13,23 & 1,89 & 3,41 & $\mathrm{C}$ \\
\hline & $(S, S)-C S P-13 d$ & 9,47 & 10,05 & 1,06 & 0,34 & $\mathrm{E}$ \\
\hline \multirow[t]{4}{*}{$\mathrm{NO}_{2}$-PEA } & $(R, R)-\mathrm{CSP}-\mathbf{1 3 a}$ & 5,42 & 12,47 & 2,30 & 2,94 & A \\
\hline & $(R, R)-C S P-13 b$ & 2,06 & 4,23 & 2,05 & 2,31 & B \\
\hline & $(R, R)-\mathrm{CSP}-13 \mathrm{c}$ & 4,83 & 7,54 & 1,56 & 1,36 & $\mathrm{C}$ \\
\hline & $(S, S)$-CSP-13d & 7,62 & 7,84 & 2,05 & $<0,2$ & $\mathrm{E}$ \\
\hline
\end{tabular}

A: acetonitril-metanol 3:7 arányú keveréke $+0,06 \% \mathrm{HCOOH}$ és 0,03\% trietil-amin

B: acetonitril-metanol 1:4 arányú keveréke $+0,04 \% \mathrm{HCOOH}$ és $0,02 \%$ trietil-amin

C: acetonitril-metanol 4:1 arányú keveréke $+0,12 \% \mathrm{HCOOH}$ és $0,08 \%$ dietil-amin.

D: acetonitril-ammónium-acetát vizes oldat $(25 \mathrm{mmol} / \mathrm{L})$ 1:4 arányú keveréke

E: acetonitril-ammónium-acetát vizes oldat $(40 \mathrm{mmol} / \mathrm{L})$ 1:4 arányú keveréke.

\subsection{Diasztereomer komplexek egykristály röntgendiffrakciós vizsgálata}

Az akridino-koronaéter alapú szenzor- és szelektormolekulák enantiomerfelismerő képességének alapjául szolgáló másodlagos kölcsönhatások azonosítása és alaposabb megértése érdekében egy, az irodalomból már ismert, dimetil-szubsztituált akridino-koronaéter, $(R, R)-16^{34}$ (5. ábra), (a fent bemutatott királis állófázisok szelektormolekuláinak analogonja) és a protonált 1-NEA enantiomerjeiből sikerült röntgendiffrakciós mérésekre alkalmas egykristályokat növeszteni. A vizsgálatok azt mutatták, hogy a heterokirális komplex $\left[(R, R)-\mathbf{1 6}-(S)-1-\mathrm{NEAH}^{+} \quad \mathrm{ClO}_{4}^{-}\right]$stabilabb, mint homokirális $\left[(R, R)-16-(R)-1-\mathrm{NEAH}^{+} \mathrm{ClO}_{4}^{-}\right]$társa (5. ábra) ${ }^{35}$. Mindkét diasztereomerben erős hidrogénkötések alakultak ki az 1-NEAH ${ }^{+} \mathrm{ClO}_{4}^{-}$ammónium-csoportjának protonjai és a koronaéter gazdamolekula megfelelő $\mathrm{N}$ és $\mathrm{O}$ atomjai között. A diasztereomerek közti legjelentösebb különbség a $\pi-\pi$ kölcsönhatás jelenlétében (heterokirális komplex), illetve hiányában (homokirális komplex) mutatkozott ${ }^{35}$.<smiles>C[C@@H]1COCCOCCOC[C@@H](C)Oc2cccc3cc4cccc(c4nc21)O3</smiles>

$(R, R)-16$<smiles>C[C@H]([NH3+])c1cccc2ccccc12</smiles>

$(R)$ - és (S)-1-NEAH ${ }^{+} \mathrm{ClO}_{4}^{-}$
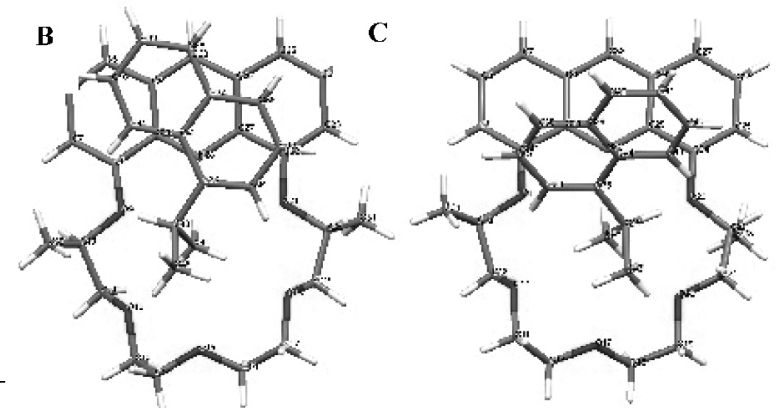

5. Ábra. (A) Egykristály röntgendiffrakcióval vizsgált gazda és vendégmolekulák, (B) heterokirális komplex, (C) homokirális komplex 


\subsection{Akridon egységet tartalmazó szenzormolekulák szintézise}

A szakirodalomban még nem közölt 17, illetve a már ismert $\mathbf{1 8}^{36}$ akridono-18-korona-6-éter alapú szenzormolekulákat a 6. ábrán bemutatott úton állítottuk elö ${ }^{38}$. A $\mathbf{1 9}^{38}$ anilin származék hangyasavval való reakciója kiváló termeléssel a 20 formamidot eredményezte. Ezt a vegyületet rézpor és réz(I)-oxid katalizálta reakcióban 2-brómanizol származékkal $\left(\mathbf{2 1}^{39}\right) \quad \mathrm{K}_{2} \mathrm{CO}_{3}$ jelenlétében, Dowtherm ${ }^{\circledR} \mathrm{A}$ oldószerben kapcsoltuk. A 22 formamid származékot vízmentes alumínium-kloriddal klórbenzolban demetileztük. Az így nyert $\mathbf{2 3}$ formamid és a $\mathbf{2 4}{ }^{40}$ ditozilát gyürüzárását kálium karbonát jelenlétében acetonitrilben végeztük el. A $\mathbf{2 5}$ koronaéter formil védőcsoportjának eltávolításával a 26 szekunder aminhoz jutottunk. A 26 aminocsoportját oxalil-kloriddal toluolban acileztük, majd katalitikus mennyiségü jód jelenlétében, brómbenzolban történő Friedel-Crafts acilezéssel a 27a izatin-származékhoz jutottunk. A 28a és 28b karbonsavakat a 27a és a korábban már közölt $\mathbf{2 7 b}^{26}$ izatinokból vizes tetrametilammóniumhidroxiddal állítottuk elő. A karbonsavak kénsav jelenlétében történő dekarboxilezése az 17 és a korábban<smiles>COc1c(C)cc(C)cc1NC=O</smiles>

19<smiles>COc1c(C)cc(C)cc1N(C=O)c1cc(C)cc(C)c1OCC(C)C(C)(C)C(=O)O</smiles>

OMe

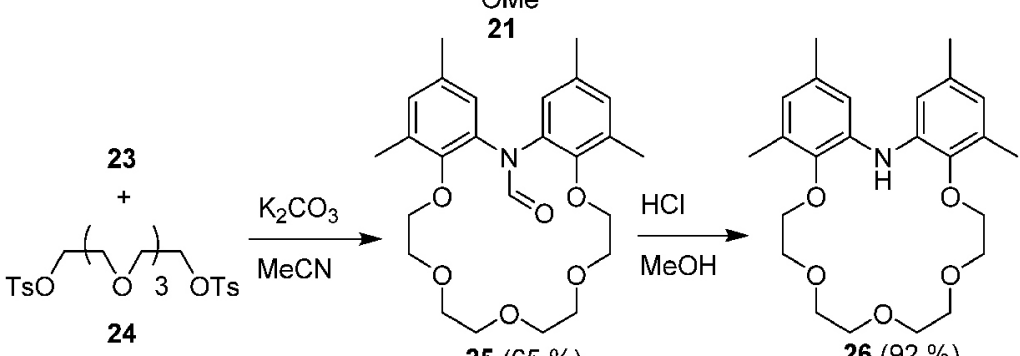

$25(65 \%)$ $26(92 \%)$

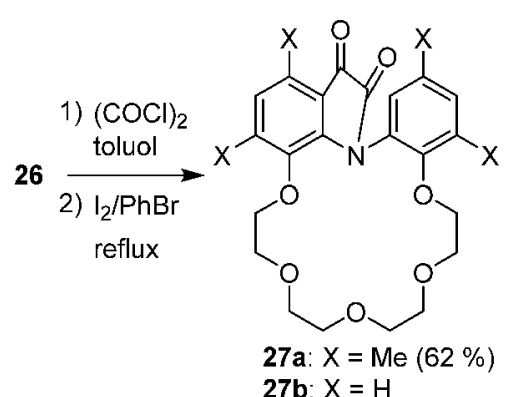<smiles>[Y14]CCOCCOCCOc1c([X])cc([X])c2c(C(=O)O)c3c([X])cc([X])c(OCCOCC([R16])C)c3nc12</smiles>

28b: $X=H(65 \%)$

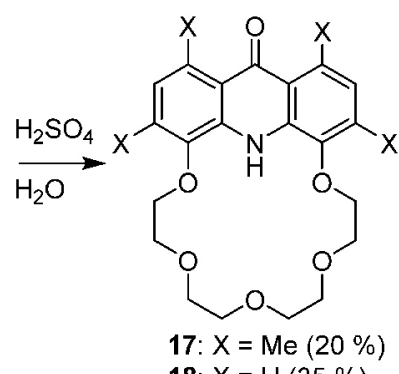

6. ábra. A 17 és 18 potenciális szenzormolekulák szintézise

\subsection{A 17 és 18 szenzormolekulák komplexképző tulajdonságainak vizsgálata UV-vis spektroszkópiával és egykristály röntgendiffrakcióval}

A 17 és 18 szenzormolekulák kilenc fémion $\left(\mathrm{Ag}^{+}, \mathrm{Ca}^{2+}\right.$, $\mathrm{Cd}^{2+}, \mathrm{K}^{+}, \mathrm{Mg}^{2+}, \mathrm{Na}^{+}, \mathrm{Ni}^{2+}, \mathrm{Pb}^{2+}, \mathrm{Zn}^{2+}$ ) perklorát sójával szemben mutatott szelektív komplexképzését acetonitril oldószerben vizsgáltuk ${ }^{37}$. A tetrametil-szubsztituált ligandum (17) abszorpciós spektruma tízszeres feleslegü fémion hozzáadására sem mutatott változást. Ez a komplexképzés hiányára vagy a komplexek alacsony stablitására vezethető vissza. Analóg királis akridono-koronaéterek vizsgálata során Szalay és munkatársai azt feltételezték, hogy a komplexálás során a ligandum hidroxiakridin tautomer formává rendeződik át ${ }^{13}$. Ezért a 17 vegyület esetében feltehetően az akridin egység elektronküldő metilcsoportokkal való szubsztitúciója gátolhatja a komplexképzésnek kedvező, 9-hidroxiakridin tautomer forma kialakulását. Továbbá a metilcsoportok jelenléte által előidézett konformációváltozás szintén a komplexálás hiányát okozhatja.

Az analóg 18 vegyület komplexképző tulajdonságait szintén vizsgáltuk, ezen vegyület esetében a vizsgált fémionok közül az ólom(II)-ion jelentős spektrális változásokat eredményezett (az abszorbancia spektrum batokróm eltolódását) (7. ábra A). Az ólom(II)?koronaéter alkotta komplex sztöchiometriájának és az egyensúlyi állandó (Ks) meghatározása érdekében UV titrálást végeztünk (7. ábra B). Felvettük az abszorbanciaspektrumot 13 különböző ólomion koncentráció esetén (a 18 koncentrációja állandó volt). A titrálás során az abszorbancia a Benesi-Hildebrand összefüggés $^{41}$ szerint változott, így 1:1 sztöchiometriát feltételeztünk. A meghatározott $\log K$ érték 3,64-nek adódott ${ }^{37}$. 

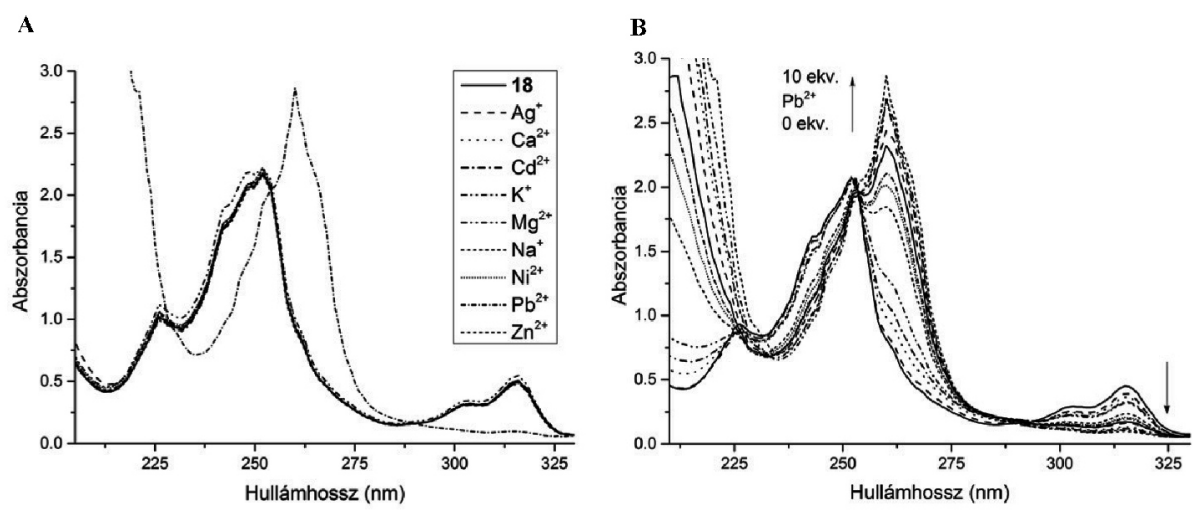

7. ábra. A 18 akridono-koronaéter fémionokkal történő komplexképzésének tanulmányozása UV-vis spektroszkópiával

A 18 akridono-koronaéter és ólom(II)-ion alkotta komplex további tanulmányozása céljából röntgenkrisztallográfiás vizsgálatokra alkalmas kristályt növesztettünk ${ }^{42}$. A mérések azt mutatták, hogy a kristályban a komplex két monomerből áll (8. ábra). A heterodimert alkotó egyik monomer egy ólom(II)-iont komplexál, a másik monomer esetében pedig a koronaéter üregében egy komplexált vízmolekula található.

\section{9-Hidroxiakridin tautomer}

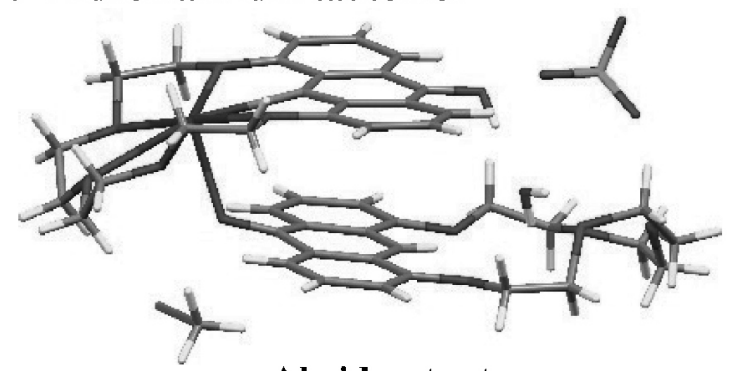

Akridon tautomer

8. Ábra. A két monomer alkotta heterodimer szerkezete. Az egyik monomer ólom(II)-iont tartalmaz a koordinációs szférájában, a másik pedig vízmolekulát komplexál

\section{Kísérleti rész}

A szintetikus munka során preparatív szerves kémiai módszereket alkalmaztunk. A reakciók elörehaladását vékonyréteg-kromatográfiával követtük. Az anyagok tisztítására oszlopkromatográfiát, preparatív vékonyréteg-kromatográfiát, átkristályosítást, illetve vákuumdesztillációt alkalmaztunk. Az anyagok tisztaságának ellenőrzésére vékonyrétegkromatográfiát, olvadáspontmérést, illetve optikai forgatóképesség-mérést használtunk. Az előállított vegyületek szerkezetét IR, ${ }^{1} \mathrm{H}$ és ${ }^{13} \mathrm{C}$ NMR, tömegspektroszkópiai, valamint elemi analízis módszerekkel igazoltuk. A három komplex kristályszerkezetének meghatározása röntgendiffrakciós méréssel történt. A királis koronaéter szelektort tartalmazó HPLC oszlopokat egy Haskel típusú pumpával készítettük el. Az oszlopok vizsgálatát Hitachi típusú HPLC rendszer alkalmazásával végeztük.

\section{Köszönetnyilvánítás}

A kutatást a Nemzeti Kutatási, Fejlesztési és Innovációs Hivatal (NKFIH, Nyilvántartási szám: OTKA/NKFIH K112289, K109486 és NK84008) és az Új Nemzeti Kiválóság Program (ÚNKP-16-3-III) pályázatok támogatták. 


\section{Hivatkozások}

1. Lehn, J.-M. Angew. Chem. Int. Ed. Engl. 1988, 27, 89-112. https://doi.org/10.1002/anie.198800891

2. Pedersen, C. J. J. Am. Chem. Soc. 1967, 89, 2495-2496. https://doi.org/10.1021/ja00986a052

3. Pedersen, C. J. J. Am. Chem. Soc. 1967, 89, 7017-7036. https://doi.org/10.1021/ja01002a035

4. Steed, J. W.; Atwood, J. L. Supramolecular Chemistry, Wiley, $2^{\text {nd }}$ ed, 2009. ISBN: 978-0-470-51234-0 https://doi.org/10.1002/9780470740880

5. Stoddart, J. F.; Szarek, W. A. Can. J. Chem. 1968, 46, 3061-3069. https://doi.org/10.1139/v68-507

6. Kyba, E. B.; Koga, K.; Sousa, L. R.; Siegel, M. G.; Cram, D. J. J. Am. Chem. Soc. 1973, 95, 2691-2692. https://doi.org/10.1021/ja00789a050

7. Anslyn, E.V.; Dougherty, D. A. Modern physical organic chemistry, University Science Books, Sausalito, California, 2005. ISBN 978-1-891389-31-3

8. Mahadevi, A. S.; Sastry, G. N. Chem. Rev. 2013, 113, 2100-2138. https://doi.org/10.1021/cr300222d

9. Newcomb, M.; Gokel, G. W.; Cram D. J. J. Am. Chem. Soc. 1974, 96, 6810-6811. https://doi.org/10.1021/ja00828a071

10. Cooper, S. R.; Crown compounds: toward future applications, Wiley, 1992.

https://doi.org/10.1002/adma.19930051031

11. Davidson, R. B.; Bradshaw, J. S.; Jones, B. A.; Dalley, N. K.; Christensen, J. J.; Izatt, R. M.; Morin, F. G.; Grant, D. M. J. Org. Chem. 1984, 49, 353-357. https://doi.org/10.1021/jo00176a026

12. Pirkle, W. H.; Pochapsky, T. C. Chem. Rev. 1989, 89, 347-362. https://doi.org/10.1021/cr00092a006

13. Szalay, L.; Farkas, V.; Vass, E.; Hollósi, M.; Móczár, I.; Pintér, Á.; Huszthy, P. Tetrahedron: Asymmetry 2004, 15, 1487-1493. https://doi.org/10.1016/j.tetasy.2004.03.024

14. Kertész, J.; Huszthy, P.; Kormos, A.; Bertha, F.; Horváth, V.; Horvai, G. Tetrahedron: Asymmetry 2009, 20, 2795-2801. https://doi.org/10.1016/j.tetasy.2009.11.011

15. Kertész, J.; Móczár, I.; Kormos, A.; Baranyai, P.; Kubinyi, M.; Tóth, K.; Huszthy, P. Tetrahedron: Asymmetry 2011, 22, 684-689. https://doi.org/10.1016/j.tetasy.2011.03.011

16. Kertész, J.; Bognár, B.; Kormos, A.; Móczár, I.; Baranyai, P.; Kubinyi, M; Kálai, T.; Hideg, K.; Huszthy, P. Tetrahedron 2011, 67, 8860-8864. https://doi.org/10.1016/j.tet.2011.09.092

17. Rapi, Zs.; Bakó, P.; Keglevich, Gy.; Baranyai, P.; Kubinyi, M.; Varga, O. J. Incl. Phenom. Macrocycl. Chem. 2014, 80, 253-261. https://doi.org/10.1007/s10847-014-0384-8

18. Subramanian, G. Chiral Separation Techniques: A Practical Approach, $3^{\text {rd }}$ ed, Wiley, 2006. https://doi.org/10.1002/9783527611737

19. Köntös, Z.; Huszthy, P.; Bradshaw, J. S.; Izatt, R. M. Tetrahedron: Asymmetry 1999, 10, 2087-2099. https://doi.org/10.1016/S0957-4166(99)00163-9

20. Köntös, Z.; Huszthy, P.; Bradshaw, J. S.; Izatt, R. M. Enantiomer 2000, 5, 561-566. ISSN:1024-2430

21. Bradshaw, J. S.; Huszthy, P.; Wang, T. M.; Zhu, C. Y.; Nazarenko, A. Y.; Izatt, R. M. Supramol. Chem. 1993, 1, 267-275. https://doi.org/10.1021/ie000272a

22. Huszthy, P.; Bradshaw, J. S.; Bodurov, A. V.; Izatt, R. M. ACH-Models Chem. 1994, 131, 445-454. ISSN:1217-8969
23. Horváth, G.; Huszthy, P. Tetrahedron: Asymmetry 1999, 10, 4573-4583. https://doi.org/10.1016/S0957-4166(99)00515-7

24. Horváth, G.; Huszthy, P.; Szarvas, S.; Szókán, G.; Redd, J. T.; Bradshaw, J. S.; Izatt, R. M. Ind. Eng. Chem. Res. 2000, 39, 3576-3581. https://doi.org/10.1021/ie000272a

25. Lévai, S.; Németh, T.; Fődi, T.; Kupai, J.; Tóth, T.; Huszthy, P.; Balogh, G. T. J. Pharm. Biomed. Anal. 2015, 115, 192-195. https://doi.org/10.1016/j.jpba.2015.07.011

26. Lakatos, S.; Fetter, J.; Bertha, F.; Huszthy, P.; Tóth, T.; Farkas, V.; Orosz, G.; Hollósi, M. Tetrahedron 2008, 64, 1012-1022. https://doi.org/10.1016/j.tet.2007.09.056

27. Németh, T.; Lévai, S.; Kormos, A.; Kupai, J.; Tóth, T.; Balogh, G. T.; Huszthy, P. Chirality 2014, 26, 651-654. https://doi.org/10.1002/chir.22361

28. Németh, T.; Dargó, G.; Petró, J. L.; Lévai, S.; Krámos, B.; Béni, Z.; Nagy J.; Balogh, G. T.; Huszthy, P.; Tóth, T. Chirality 2017 https://doi.org/10.1002/chir.22721

29. Samu, E.; Huszthy P.; Somogyi, L.; Hollósi, M. Tetrahedron: Asymmetry 1999, 10, 2775-2795. https://doi.org/10.1016/S0957-4166(99)00287-6

30. Székely, Gy.; Csordás, B.; Farkas, V.; Kupai, J.; Pogány, P.; Sánta, Zs.; Szakács, Z.; Tóth, T.; Hollósi, M.; Nyitrai, J.; Huszthy, P. Eur. J. Org. Chem. 2012, 18, 3396-3407. https://doi.org/10.1002/ejoc.201101769

31. Cooper, K. D.; Walborsky, H. M. J. Org. Chem. 1981, 46, 2110-2116. https://doi.org/10.1021/jo00323a026

32. Kirkland, J. J.; De Stefano, J. In Advances in Chromatography, Grinberg, N., Ed.; CRC Press, 2015, Vol. 50, pp 281-296. ISBN: 9781439858448

33. Németh, T.; Lévai, S.; Fődi, T.; Kupai, J.; Túrós, G.; Tóth, T.; Huszthy, P.; Balogh, G. T. Journal of Chromatographic Science 2015, 53, 431-435. https://doi.org/10.1093/chromsci/bmu157

34. Huszthy, P.; Samu, E.; Vermes, B.; Mezey-Vándor, G.; Nógrádi, M.; Bradshaw, J. S.; Izatt, R. M. Tetrahedron 1999, 55, 1491-1504.

https://doi.org/10.1016/S0040-4020(98)01128-4

35. Tóth, T.; Németh, T.; Leveles, I.; Vértessy, B. G.; Huszthy, P. Struct. Chem. 2017, 28, 289-296. https://doi.org/10.1007/s11224-016-0818-6

36. Huszthy, P.; Köntös, Z.; Vermes, B.; Pintér, Á. Tetrahedron 2001, 57, 4967-4975. https://doi.org/10.1016/S0040-4020(01)00408-2

37. Németh, T.; Kormos, A.; Tóth, T.; Balogh, G. T.; Huszthy, P. Monatsh Chem 2015, 146, 1291-1297. https://doi.org/10.1007/s00706-015-1454-3

38. Andrews, B. D.; Poynton, A. J.; Rae, I. D. Aust. J. Chem. 1972, 25, 639-646. https://doi.org/10.1071/CH9720639

39. Oikawa, N.; Nakagawa, Y.; Nishimura, K.; Ueno, T.; Fujita, T. Pestic. Sci. 1994, 41, 139-148. https://doi.org/10.1002/ps.2780410210

40. Bonger, K. M.; van den Berg, R. J. B. H. N.; Heitman, L. H.; Ijzerman, A. P.; Oosterom, J.; Timmers, C. M.; Overkleeft, H. S.; van der Marel, G. A. Bioorg. Med.Chem. 2007, 15, 4841-4856. https://doi.org/10.1016/j.bmc.2007.04.065

41. Benesi, H. A.; Hildebrand, J. H. J. Am. Chem. Soc. 1949, 71, 2703-2707. https://doi.org/10.1021/ja01176a030

42. Németh, T.; Golcs, Á.; Leveles, I.; Tóth, T.; Vértessy, B. G.; Huszthy, P. Struct. Chem. 2015, 26, 1467-1471. https://doi.org/10.1007/s11224-015-0657-x 
Synthesis, enantiomeric and cation recognition studies of acridino- and acridono-crown ether-based sensor and selector molecules

Development of sensor and selector molecules for the analysis of metal ions and for selective recognition and separation of the enantiomers of chiral molecules is of great interest due to their potential applications in pharmaceutical and food industries as well as in environmental chemistry. The complexing ability of these sensors and selectors is based on molecular recognition. The action of this phenomenon can be best described as a selective discrimination between two or more molecules by which non-covalent interactions ordered structures, complexes are formed. Good examples for the action of molecular recognition are the double-helix formation of DNA and the selective metal ion binding and transport of natural ionophores across biological membranes. Complexes formed by the action of molecular recognition are held together by non-covalent forces emerging between stereoelectronically complementary groups. Previously, molecular recognition was considered as a biological phenomenon, but findings of the past few decades clearly proved that it can be brought about by relatively simple synthetic molecules, such as crown ethers.

Our research was focused on the synthesis and molecular recognition studies of new achiral and enantiomerically pure sensor and selector molecules and their precursors based on acridono- and acridino-18-crown-6 and 21-crown-7 ethers. The metal ion and enantiomeric selectivities of the new ligands were studied using UV-vis and fluorescence spectroscopies. Furthermore, four new HPLC columns filled with acridino-crown ether-based chiral stationary phases were prepared. Their chromatographic enantioseparation ability for the mixtures of enantiomers of protonated primary amino compounds containing an aromatic moiety was demonstrated.

The synthesis and characterization of new alkyl-substituted crown ethers $(R, R)-\mathbf{1 1} \mathbf{a},(S, S)-\mathbf{1 1} \mathbf{b},(S, S)-\mathbf{1 1} \mathbf{c},(R, R)-\mathbf{1 1 d}$ and $(R, R)$-11e containing a 9-acridinecarboxylic acid subunit have been achieved ${ }^{27,28}$ (3. Ábra). Using macrocycles $(R, R)-11 \mathbf{a},(S, S)-\mathbf{1 1} \mathbf{b}$ and $(R, R)-\mathbf{1 1} \mathbf{e}$ the preparation of the new acridino-18-crown-6 ether-based CSPs [(R,R)-CSP-13a, $(R, R)$-CSP-13b and $(S, S)$-CSP-13d] was accomplished by traditional batch process applying the slurry-packing technique (4. Ábra). Furthermore, a new and effective continuous recirculation method has been elaborated for the preparation of an acridino-18-crown-6 ether-based chiral stationary phase $(R, R)$-CSP-13c (4. Ábra $)^{33}$. We studied the enantiomeric separation abilities of the novel CSPs by HPLC. We demonstrated that chiral stationary phases $(R, R)$-CSP-13a and $(R, R)$-CSP-13b separated the mixtures of enantiomers of selected protonated primary aralkylamines efficiently. Both chiral stationary phases showed the best separation factors for the separation of the mixtures of enantiomers of $\mathrm{NO}_{2}-\mathrm{PEAH}^{+}$. We found that the bulkiness of the alkyl substituents at the chiral centers has an effect on the degree of enantiomeric recognition; diisobutyl-substituted $(R, R)$-CSP-13a showed the highest selectivity for all analytes among all acridino-crown ether-based CSPs.

In the case of $(R, R)$-CSP-13c, prepared by the flow chemistry method, the best results were achieved for the separation of the mixtures of enantiomers of $\mathrm{Br}-\mathrm{PEAH}^{+}$. Highest resolution factors were achieved by this CSP among all acridino-crown ether-based CSPs.

Regarding $(R, R)$-CSP-13d homochiral preference was found for the studied analytes and the best separation was achieved for the enantiomers of $1-\mathrm{NEAH}^{+}$. We concluded that the position of the chiral center is crucial for the degree of enantiomeric recognition; placing the methyl groups further away from the acridine moiety decreases the degree of enantioselectivity, by decreasing steric hindrance between the host and guest molecules ${ }^{28}$.

21-crown-7 ethers $(S, S)-11 \mathrm{c}$ and $(R, R)$-11d are key intermediates for the synthesis of enantioselective sensor and selector molecules for protonated chiral primary amines, amino acids and their derivatives. These crown ether derivatives can easily be attached to silica gel with covalent bonds to produce new CSPs.

In order to study the non-covalent interactions affecting the enantiomeric recognition of sensors and selectors based on crown ethers we prepared suitable crystals for X-ray analysis from the dimethyl-substituted acridino-18-crown-6 ether $(R, R)-16$ and the enantiomers of $1-\mathrm{NEAH}^{+}(5 \text {. Ábra })^{35}$. The measurements revealed that the heterochiral complex $(R, R)-16-(S)-1-\mathrm{NEAH}^{+}$is more stable than the homochiral one $(R, R)-16-(R)-1-\mathrm{NEAH}^{+}$. In the case of the heterochiral complex, the presence of a strong $\pi-\pi$ interaction was found between the naphthyl unit and the acridine moiety, but in the case of the homochiral complex $\pi-\pi$ interaction was not present. We suggest that the presence or absence of the $\pi-\pi$ interaction and the difference in steric repulsions were responsible for the enantiomeric selectivity. These results may provide grounds for the interpretation of the chiral recognition phenomenon of acridino and related crown ethers.

Additionally, the synthesis of the new acridono-18-crown-6 ether type sensor 17 (6. Ábra) has been carried out starting from commercially available and relatively cheap materials $\mathrm{s}^{37}$. The cation recognition ability of ligand $\mathbf{1 7}$ and its reported analogue $\mathbf{1 8}$ toward various metal ions was studied in acetonitrile by UV-vis spectroscopy. Our studies revealed the selective binding of lead(II) ions by acridono-18-crown-6 ligand 18 (7. Ábra). Based on our calculations we suggest the formation of a complex with a 1:1 ligand to metal ion ratio. In order to comprehend better 
the forces behind the selective lead(II) ion complexation of 18, suitable crystals for XRD measurements have been prepared $^{42}$. The results show a $\pi-\pi$ bonded heterodimer in the crystal (8. Ábra). One part of the dimer changes to the 9-hydroxyacridine tautomeric form upon lead(II) complexation, in which the lead(II) ion is eight-coordinated and fits well into the cavity of the macrocycle. The other part of the dimer stays in the $9(10 H)$-acridone tautomeric form, which favors water complexation. The average bond distance of the two tricyclic units (3.5 Ĺ) indicated a strong $\pi-\pi$ interaction. The X-ray studies also revealed a cation $-\pi$ interaction between lead(II) and the electron rich acridone moiety. 